\section{Politics, Ethnicity, and the Mission of the University: The Kenyan Example}

\author{
WyCliffe OtIENO \\ Wycliffe Otieno is lecturer in the Department of Education Administration \\ at Kenyatta University, POH 43844, Nairobi, Kenya. E-mail: wotieno@e- \\ parse.or.ke.
}

$\mathrm{T}$ he vulnerability of the education sector to the risks of political instability became clearly evident during the flare-up of violence following the disputed 2007 presidential elections in Kenya. Whereas universities especially in the developing world have often been seen as breeding grounds for radical political ideas and student activism, the postelection violence in Kenya directly affected university education, on a scale no other event has in the country's history. And, for the first time, the crisis facing education generally, and higher education specifically, showed clear ethnic manifestations.

Because universities are located in geographical areas dominated by specific ethnic communities, professors perceived to belong to different communities other than the dominant ones saw their homes burned and were evicted or forced to flee. Their businesses were destroyed. Institutions remained closed for the fear that having students on campus would aggravate the situation by taking sides. The state dreaded such a specter; yet, it had a pervasive desire to demonstrate a quick return to normalcy. Thus, institutions choosing to open had to come up with innovative measures to forestall any violence.

In the midst of the chaos Kenyatta University, the country's second-largest university, decided to open by putting in place measures to manage possible student unrest and staff restiveness. This policy entailed joint meetings of administrative and academic staff, a temporary ban on social groupings and meetings, counseling services for students and staff directly affected, holding talks with the local community where some students are housed so as not to be hostile to students from other ethnic groups, and a waiver of mandatory full-fee payment requirement before admission of students. Other universities (e.g., Maseno University) postponed opening by four months-more than the duration of a full semester. The University of Nairobi opened a month later than schedule but almost shut down because of ethnic tensions among students.

How institutions respond to crises may be evaluated from the perspective of the missions of the university that are most relevant here: promoting diversity and/or universalism and nurturing academic freedom. These are issues enshrined in the Kenyan constitution and education philosophy.

\section{UNIVERSALISM OF THE UNIVERSITY AND ETHNIC QUESTION} The university is "universal" in character and composition. While it may not be exactly supranational, it is a super national institution. The promotion of national cohesion is a core objective of higher education in Kenya. Some coverage of the postelection violence in Kenya (e.g., www.universityworld news.com/article.php?) applauded Kenyatta University's reopening of campus as a lesson in diversity. The otherwise objective report failed to bring out the deeper dynamics of typical public behavior as an offshoot of a highly politicized and ethnicized bureaucracy that runs directly counter to the university's mission. The University World News' report failed to appreciate the close political linkage between public institutions and the political leadership of the day. Despite the muchhyped reforms in 2003 , vice chancellors in Kenya remain political appointees beholden to the government and, naturally, remain politically compliant.

A direct outcome of this political compliance is a continued ethnicization of university administration, with the appointment of key university personnel from members of one ethnic community and region remaining a key feature. The ethnic bond serves both sides equally: the political patrons find avenues for rewarding their supporters while the administrator also finds an opportunity to create a strong base of loyal academics and administrators from his or her own ethnic stronghold. With loyal members, one faces little difficulty in manipulating the university senate and the council.

Controlling the mainstream administration is but one step in containing, or at least placating, internal opposition. The top management also needs to control student politics. Again, this takes a familiarly predictable pattern: influencing the election of students from specific ethnic blocks to the student leadership. However, widespread concerns arise that the university administration is already tribalized, the task proves trickier. Some public universities have openly tried to influence the election of student leaders from specific ethnic communities. In one university in 2007 , such efforts boomeranged as students from a dozen other communities united to vote against the preferred candidates. As a result, the ethnic composition of the student leadership at a particular university contrasts sharply with that of the university administration. One need not go far to see how averse the university administration is to diversity. Statistics on lecturers sacked as a result of the 2006 faculty strike at one particular university provide sufficient proof. Virtually none of the lecturers were from one region of the country, dominated by specific ethnic groups. The action was therefore widely condemned as ethnicized dismissal. Hiring procedures are, to a great degree, ethnically influenced.

\section{ACADEMIC FreEdom}

One of the responses by Kenyatta University to contain possible backlash was to restrict lecturers in particular disciplines from teaching specific topics or giving particular examples-a clear gagging of academic freedom. Equally, banning social 
meetings (even if only temporarily) is an infringement on individual rights of association. It is insincere that such meetings can be banned when students from one ethnic community heavily represented in university administration are able to caucus freely in the offices of these administrators and lecturers. The many examples of insincerity on the campus are further evident in the caution staff received against using their mother tongue. It is common knowledge in the country that the members of one ethnic community have almost institutionalized the use of mother tongue in what are otherwise public offices in the three years of the current administration.

Clearly, some of the measures amount to bribery. Kenyatta University is known to normally insist on a Ioo percent fees payment before admission. However, this time around, to court students, this condition has been waived. Students are therefore happy because they have been given a reprieve where they are most vulnerable: finances. Any pacification, as in Kenyatta's case, that ameliorates students' financial burden is one of the most powerful tools of appeasement. Unfortunately, for Kenyatta, as soon as normalcy returns, the waiver is likely to be dispensed with. And this may just bring more trouble on campus.

\section{New Publications}

Barblan, Andris, Ustun Ergruder, and Kemal Gürüz. Higher Education in Turkey: Institutional Autonomy and Responsibility in a Modernizing Society. Bologna, Italy: Bononia University Press, 2008. 2I3 pp. (pb). ISBN 978-88-7395-34I-8. Web site: www.

buponline.com.

A historical and contemporary analysis of Turkish higher education, this volume combines analysis with recommendations for the organization reform of Turkish higher education by two key Turkish higher education experts.

Bousquet, Marc. How the University Works: Higher Education and the Low-Wage Nation. New York: New York University Press, 2008. 280 pp. \$22 (pb). ISBN 978-0-8I47-9975-8. Web site: www.nyupress.org.

A detailed analysis of faculty unionization, the problems of part-time and other teachers at the lower end of the academic hierarchy in the United States, the issues facing students and their efforts to unionize in higher education, this book takes a partisan approach to these themes. It is, however, one of the few books to discuss the problems faced by a large number of professionals in American colleges and universities.

Buller, Jeffrey L. The Essential Academic Dean: A Practical Guide to College Leadership. San Francisco: Jossey-Bass, 2007. 43I pp. \$30 (pb). ISBN 978-0-470-I8086-0. Web site: www.josseybass.com.

Written from an American perspective, this book provides a thorough discussion of the role of the academic dean in higher education. The author, an experienced dean him- self, provides a discussion of the role of dean and practical suggestions for successful performance. Among the themes discussed are the constituents of a dean, the dean's staff, leadership, career paths, and related topics.

Council on Higher Education. Review of Higher Education in South Africa: Selected Themes. Pretoria, South Africa: Council on Higher Education, 2007. I88 pp. (pb). ISBN 978-I-9I9856-6I-2. Web site: www.che.ac.za.

A reconsideration of policy areas in South African higher education, this volume provides a research-based analysis of key sectors. Among the themes analyzed in the book are public funding and its problems, information and communications technology, institutional governance and public accountability, institutional culture, access issues for adult learners, and problems of change in higher education.

De Wit, Hans, Pawan Agarwal, Mohsen Elmahdy Said, Molatlhegi T. Sehoole, and Muhammed Sirozi, eds. The Dynamics of International Student Circulation in a Global Context. Rotterdam, Netherlands: Sense Publishers, 2008. 266 pp. \$49 (pb). ISBN 978-90-8790-258-2.

Web site:www.sensepublishers.com.

Student mobility is the most important part of the internationalization of higher education. This volume is the first one that carefully analyzes student mobility mainly in developing countries. Case studies of India, Indonesia, Egypt, and South Africa are included, along with general considerations of global student circulation and a discussion of the impact of the EU's Bologna and Lisbon strategies.
Epstein, Debbie, Rebecca Boden, Rosemary Deem, Fazal Rizvi, and Susan Wright, eds. Geographies of Knowledge, Geometries of Power: Framing the Future of Higher Education. New York: Routledge, 2007. 395 pp. (hb). ISBN 978-0-4I5-96378. Web site: www.routledge .com/education.

The focus of this volume of the World Yearbook of Higher Education is higher education. The chapters are unified by a critical perspective on higher education developments worldwide. Among the themes discussed are internationalization, transnational academic flows of both students and faculty, private higher education, GATS and WTO, academic leadership, and others.

Gürüz, Kemal. Higher Education and International Student Mobility in the Global Knowledge Economy. Albany: State University of New York Press, 2008. 335 pp. \$75 (hb). ISBN 978-0-79I4-74I3-6. Web site: www. sunypress.edu.

A wide-ranging discussion of the underlying factors of higher education globalization, including broad economic forces, the rise of the for-profit sector, information technology, and others, this book links these factors to higher education developments in general and to student mobility in particular. The author, a researcher and policymaker in Turkey, brings a global perspective to this discussion.

Educación Superior en Iberoamérica. Informe 2007. [Higher Education in Ibero-America. 2007 Report] Santiago, Chile: CINDA, Centro Interuniversitario de Desarrollo, Santa Magdalena 75, Piso II, Providencia, Santiago, Chile. ISBN 978-956-7I06-50-9. Web site: www.cinda.cl. 